УДК 37. 015. 3

DOI: $\underline{10.35619 / \text { iiu.v2i11.263 }}$

Павелків Роман доктор психологічних наук, професор, перший проректор, завідувач кафедри вікової та педагогічної психології Рівненського державного гуманітарного університету, м. Рівне, Україна ORCID: 0000-0002-6564-4507 e-mail:pavelkiv_rv@ukr.net

\title{
СУЧАСНІ ПІДХОДИ ДО ВИЗНАЧЕННЯ СУТНОСТІ ПОНЯТТЯ «ОСВІТНІЙ ПРОСТІР»
}

Анотація. У статті схарактеризовано сучасні підходи до визначення сутності поняття «освітній простір» у контексті реалізації Концепції «Нова українська школа». 3’ясовано, що вчені намагаються знайти баланс у підходах до вивчення та тлумачення змістового наповнення й структури поняття «освітній простір». У цьому контексті проаналізовано погляди Л. Виготського, М. Віленського, В. Касторнової, Д. Косенка, К. Крутій, Є. Мещерякової, І. Фруміна, А. Цимбалару, І. Шендрика, О. Ярошинської, В. Ясвіна та ін.

Освітній простір визначено як особливий простір, у якому процеси освіти особистості відбуваються у ході трансляції культури підростаючим поколінням. Його по праву вважають основним поняттям теорії педагогіки.

Схарактеризовано основні підходи вітчизняних і зарубіжних дослідників до розуміння «освітнього простору», як-от: системно-цілісний, ментально-емоційний, особистіснорозвивальний, соціально-географічний, дистанційний і локально-стендовий. 3'ясовано, що спільними характеристиками для них $\epsilon$ : системність, наявність просторових координат, розгляд елементів системи не ізольовано, а цілісно, інформаційність простору, територіальна цілісність освіти, особистісна спрямованість навчання. Основною ж відмінністю між визначеними підходами $є$ означення сутності, основного ядра освітнього простору.

Доведено, що введення відповідного розуміння поняття «освітній простір», розмежування його $з$ поняттям «освітнє середовище» вносить логічне розуміння взаємозв'язку цих понять, дає змогу розвивати нові концепції й уявлення, які з'являються останніми роками, позаяк за допомогою організації освітнього простору класної кімнати можна впливати на мотивацію учнів, формувати сприятливу атмосферу, задовольняти освітні потреби учнів Нової української школи.

Ключові слова: освітній простір, поняття, педагогічні підходи, Нова українська школа, освітнє середовище.

Постановка проблеми. Упровадження в освітній процес Концепції «Нова українська школа» (Нова українська школа, 2016) передбачає урізноманітнення організації освітнього середовища і формування нового освітнього простору.

Проблема створення сучасного освітнього простору $є$ предметом дослідження як педагогів, так і психологів, соціологів, ергономістів й т. п. Результати таких досліджень, 3 одного боку, грунтуються на спільних підходах до сучасного освітнього простору, а з іншого 
- враховують місцеві передумови та можливості. Для формування освітнього простору Нової української школи доцільно визначити, яким чином актуальні принципи та підходи до організації освітнього простору можуть бути реалізовані в сучасній початковій школі 3 метою якнайкращого облаштування необхідних повноцінних зон у просторі класної кімнати.

Аналіз останніх досліджень 3 проблеми. Проблема організації освітнього простору не $\epsilon$ новою в педагогіці і психології. Приміром, ще на початку XX ст. О. Декролі, Марія Монтессорі, Рудольф Штайнер розробили чіткі рекомендації вчителям щодо організації простору класу, змістовного наповнення й функціоналу кожної зони класної кімнати. Особливістю цих підходів $є$ урізноманітнення освітнього простору, створення можливостей для різноманітних видів діяльності, а не лише для сидіння за партами. Так, Монтессорісередовище передбачає обладнання в класній кімнаті певної кількості спеціально облаштованих «осередків» для розміщення матеріалів та діяльності учнів - тобто послідовно втілюється принцип функціонального зонування освітнього приміщення.

У 60-х рр. ХХ ст. активно впроваджувався підхід «гнучкого навчального простору», який передбачав створення можливості для урізноманітнення форм навчальної роботи не за рахунок розширення асортименту меблів, а в першу чергу через зміни розташування обладнання в просторі класу (Степанов та Дворкина, 1977).

Саме поняття «освітній простір» з'явилося в педагогічній термінології наприкінці 80-х pp. XX ст. як об'єднане значення двох понять: простір і освітній. Освітній простір визначався як такий, що забезпечує можливості для формування «духовного обличчя людини, яке складається під впливом моральних і духовних цінностей, що є надбанням іiі культурного кола, а також процес виховання, самовиховання, впливу, шліфування, процес формування обличчя людини» (Копиленко, 2001, с.241).

Поняття освітнього простору вивчається упродовж останніх десятиріч як вітчизняними, так і зарубіжними вченими. Аналіз досліджень науковців засвідчує про багатовимірність і різноплановість поняття «освітній простір». Більшість дослідників означеної проблеми (Н. Бастун, С. Бондирєва, С. Гершунський, Б. Серіков, В. Слободчиков, І. Фрумін та ін.) під поняттям «освітній простір» розуміють певну територію, яка пов'язана 3 масштабними явищами в галузі освіти: як певна частина соціального простору, у межах якої здійснюється нормована освітня діяльність; як єдність, цілісне утворення в галузі освіти, яке має свої межі, що уточнюються окремо, - світовий освітній простір, міжнародний освітній простір, європейський освітній простір, освітній простір регіону, школи, шкільного класу тощо (Момот та Шелестова, 1997).

Сучасні психологи і педагоги шукають баланс між підходами до вивчення, тлумачення змістового наповнення й структури поняття «освітній простір». Приміром, В. Панов i В. Ясвін виокремлюють такі основні його компоненти: соціальний, просторово-предметний, психодидактичний (Ясвин, 2001). Натомість Н. Колесникова виокремлює фізичні, соціокультурні, психологічні, комунікативні, віртуальні, парадигмальні характеристики освітнього простору. У педагогічній літературі також виокремлюють такі складові простору, як рівні (методологічний, методичний та ін.), сегменти (виховний простір, інформаційний простір, індивідуальні простори учасників освітньо-виховного процесу та ін.), поля (етичне та ін.) та інші конструкти й вузлові структури (Осмоловський та Василенко, 2000).

3 метою вирішення завдання організації сучасного освітнього простору Міністерством освіти та науки ухвалено «Методичні рекомендації щодо організації освітнього простору Нової української школи» (Міністерство освіти і науки України, 2018). 
Мета статті - схарактеризувати основні сучасні підходи до визначення сутності освітнього простору.

Виклад основного матеріалу дослідження. Сучасна наука тлумачить освітній простір як існуюче в соціумі «місце», де суб'єктивно задаються безлічі відносин і зв'язків, де здійснюється спеціальна діяльність різних систем (державних, суспільних і змішаних) 3 розвитку особистості.

Поняття освітнього простору поєднує дві основні ідеї: ідею простору та ідею освіти. Освітній простір відображає певне структурне співіснування i взаємодію будь-яких можливих освітніх систем, їх компонентів, освітніх подій.

Освітній простір розглядається як складна система, що розвивається, динамічна єдність суб'єктів освітнього процесу і їх відносин.

Освітній простір є сферою взаємодії трьох його суб'єктів: учителя, учня й середовища між ними. Висновок відомого психолога Л. Виготського про тристоронній активний процес (активний учень, активний учитель, активне середовище між ними) дає змогу розглядати трикомпонентну взаємодію суб'єктів освітнього простору як єдиний процес цілеспрямованого формування особистості дитини, не розділяючи виховання й освіту (Выготский, 1996). У цьому процесі взаємодія суб'єктів освітнього простору, учителя й учня представлена як активні взаємини із середовищем, яке можна розглядати як інформаційний компонент освітнього простору, структурованого так, що він сам активно впливає на інших суб'єктів освітнього простору. Ця структура може бути визначена як «ідеальна форма середовища» (Л. Виготський). Ключовою фігурою в освітньому просторі, поза сумнівом, $\epsilon$ педагог. Активна взаємодія суб' єктів освітнього процесу виформовує «середовище спільної діяльності» (Выготский, 1996).

I. Фрумін, який виокремив в освітньому просторі ідеальні об'єкти і порожні місця, що утворюються, існують і розвиваються в часі, зміг визначити також такий вектор формування освітнього простору, як розгортання. Його очікуваним результатом $\epsilon$ досягнення не реактивної (репродуктивної), а активної (із наявним творчим продуктом) дії. Суб'єкти освітнього простору активно взаємодіють із середовищем, яке розглядається в якості інформаційного компонента освітнього простору, структурованого так, що воно здійснює активний вплив на інших суб' єктів освітнього простору.

Своєю чергою, І. Шендрик розглядає освітній простір як утворення, що виникає у результаті взаємодії учня і педагога, і оптимальним шляхом його формування визначає проєктування їх спільної дії. Розуміння учня як «відкритої системи, яка знаходиться у постійній взаємодії з навколишнім світом» і є суб'єктом власного розвитку, здатним до «вільного вибору на основі співвіднесення суб'єктом себе, своїх особливостей i оточуючого» (Шендрик, 2003, с.103), є підставою для вибору механізмів створення освітнього простору особистості.

Натомість, О. Ярошинська вважає, що «освітній простір є багаторівневим соціокультурним сегментом, у межах якого на певній території реалізуються різні рівні взаємодії людини з оточуючими іiі елементами - носіями культури (освітнім середовищем), що створюють потенційні можливості для розвитку особистості» (Ярошинська, 2014, с.59).

Розглядаючи освітній простір як педагогічну категорію, М. Віленський і $Є$. Мещерякова здійснили аналіз вживання поняття «освітній простір» у науковій літературі, виокремлюючи такі підходи вітчизняних і зарубіжних авторів у розумінні «освітнього простору»: системноцілісний, ментально-емоційний, особистісно-розвивальний, соціально-географічний, дистанційний і локально-стендовий (Виленский, 2002). Для всіх перерахованих підходів загальним є застосування єдиних характеристик: системності; наявності просторових 
координат; розгляду елементів системи не ізольовано, а цілісно; інформаційності простору; територіальної цілісності освіти; особистісної спрямованості навчання. Основною ж відмінністю між визначеними підходами є визначення сутності, основного ядра освітнього простору.

У межах системно-цілісного підходу (Г. Сєріков) під освітнім простором розуміється своєрідний елемент суспільної формації і продукт життєдіяльності людини у формі вкладених одна в одну освітніх систем, де більша система відносно менших систем утворює відповідний освітній простір.

Ментально-емоційний підхід (Р. Еверман, Ю. Копиленко) на перше місце висуває значущість розвитку ментальних і емоційних можливостей і здібностей особистості, а також пов'язану з цим необхідність удосконалення методик і технологій їх формування і розвитку.

Особистісно-розвивальний підхід (J. Sechrest, J. Parker) у якості провідного компонента освітнього простору розглядає особистість учня і його взаємодію із змістом, методиками $\mathrm{i}$ технологіями освіти.

У межах соціально-географічного підходу (В. Кінєльов, О. Сошнєва) основна увага приділяється створенню єдиного освітнього простору i єдиного інформаційного середовища.

У межах дистанційного підходу (A. W. Bates, T. Evans) пропонується вдосконалення методик, які використовуються в освітньому просторі, нових засобів, незалежність учнів, текстову комунікацію в освітньому просторі.

У локально-стендовому підході (Л. Санкін, M. Cesaroni, Е. Kopachkov) вводиться поняття малого освітнього простору окремо взятої освітньої установи, класу в реальній дійсності (Касторнова, 2014).

Таким чином, переважаючим підходом до інтерпретації поняття «освітній простір» у сучасній педагогіці є уявлення про нього як про місце, точку й одночасно процес, у ході якого здійснюється та або інша форма контакту особистості й середовища. Освітній простір в більшості досліджень постулюється в якості складової частини середовища, що відрізняється від останнього тим, що він $є$ місцем взаємодії людини й середовища.

Д. Косенко вважає, що освітній простір - це, насамперед, «матеріальні засоби освіти: архітектура та інтер'єр шкільної будівлі, меблювання та обладнання, різноманітне навчальне приладдя тощо» (Косенко, 2018). Натомість, А. Цимбалару тлумачить «освітній простір школи» як просторово-предметний компонент - предметні засоби, сукупність та певне розташування яких створює умови для організації потрібних дій суб'єктів. Він уміщує виховний, розвивальний, навчальний, педагогічний простори тощо. Вона визначає освітній простір школи як складне утворення, що складається з освітнього простору кожного учня, кожного вчителя, кожного з батьків тощо; як події, у яких здійснюються різні види діяльності кожного учасника освітнього процесу 3 освоєння шкільного середовища, необхідні для задоволення їхніх освітніх потреб (Цимбалару, 2016).

На думку К. Крутій, «освітній простір» відноситься до складних, багатоаспектних педагогічних явищ, які характеризуються не стільки кількісними, скільки якісними показниками (Крутій, 2009).

При цьому розвивальний потенціал освітнього простору забезпечується можливістю для всіх суб'єктів освітнього процесу взаємодіяти із середовищем, здійснювати просторовий i предметний вибір, змінювати, конструювати його в процесі власної діяльності. Освітній простір класної кімнати - це місце докладання зусиль дитини, спрямованих на осмислення себе, своїх потреб, інтересів, бажань. Він виступає результатом засвоєння, усвідомлення й осмислення об'єктивної реальності, яка виникає в процесі взаємодії особистості 3 
навколишньою дійсністю. Освітній простір класної кімнати виступає як поле актуальних можливостей. Самі по собі об'єкти простору не створюють. Для цього необхідне специфічне «накладання» вектора особистісних або соціальних ставлень, які й структурують об'єкти відносно один одного, тобто створюють «простір» (Швалб, Вернік, Вовчик-Блакитна та Рудоміно-Дусятська, 2015).

Висновки і перспективи подальших розвідок. Отже, сучасні педагогічні дослідження визначають освітній простір як особливий простір, у якому процеси освіти особистості відбуваються в ході трансляції культури підростаючим поколінням; його по праву визнають основним поняттям теорії педагогіки. Уведення нового розуміння поняття «освітній простір», розмежування його 3 «освітнім середовищем» вносить логічне розуміння взаємозв'язку цих понять, дає змогу розвивати нові концепції й уявлення, які з'являються останніми роками. За допомогою організації освітнього простору класної кімнати можна впливати на мотивацію учнів, формувати сприятливу атмосферу, задовольняти освітні потреби учнів.

Перспективу подальших наукових розвідок вбачаємо у здійсненні міждисциплінарних досліджень освітнього простору класної кімнати, які сприятимуть ефективній модернізації освітнього простору Нової української школи.

\section{СПИСОК ВИКОРИСТАНИХ ДЖЕРЕЛ}

Нова українська школа (2016). Концептуальні засади реформування середньої иколи. Київ: МОН, 40 с.

Степанов,В. Дворкина Е. (1977). Новые типь средних образовательных школ с гибкой планировочной структурой. Москва: Стройиздат. 235 с.

Копиленко, Н. (2001). Педагогічний словник. Київ: Педагогічна думка. 516 с.

Момот, Л. та Шелестова, Л. (1997). До проблеми формування творчих здібностей у процесі навчання. Педагогіка і психологія. №2. с. 53-59.

Ясвин, В. (2001). Образовательная среда: от моделирования к проектированию. Москва: Смысл, 365 с.

Осмоловський, А. та Василенко, Л. (2000). Від навчального проекту до соціальної самореалізації особистості. Шлях освіти. №2. с.34-37.

Міністерство освіти і науки України (2018). «Про затвердження Методичних рекомендації щодо організації освітнього простору Нової української школи. URL: https://imzo.gov.ua/2018/03/25/nakaz-mon-vid-23-03-2018-283-pro-zatverdzhennyametodychnyh-rekomendatsij-schodo-orhanizatsiji-osvitnoho-prostoru-novoji-ukrajinskoji-shkoly/ [Дата звернення 26.03.2020].

Выготский, Л. (1996). Педагогическая психология. Москва: Педагогика-Пресс, 536 с.

Шендрик И. (2003). Образовательное пространство субъекта и его проектирование. Москва: АПКиПРО. 156 с.

Ярошинська О. (2014). Проектування освітнього середовищза професійної підготовки майбутніх учителів початкової школи: монографія. Умань : Жовтий О. О. 456 с.

Виленский, М. та Мещерякова, Е. 2002. Образовательное пространство как педагогическая категория. Педагогическое образование и наука. Москва. с. 8-18.

Косенко, Д. (2018). Новий освітній простір для Нової української школи: місія нездійснена?! URL: http://education-ua.org/ua/articles/1115-novij-osvitnij-prostir-dlya-novojiukrajinskoji-shkoli-misiya-nezdijsnena [Дата звернення 20.03.2020].

Касторнова, В. (2014). Некоторые подходы к определению образовательного пространства. Педагогическое образование в России. №8. С. 43-48. 
Цимбалару, А. (2016). Освітній простір: сутність, структура і механізми створення. Украйнський педагогічний журнал. № 1.0 URL: http://uej.undip.org.ua/upload/iblock/311/311c4a2491b1cdb734b792dca919716e.pdf [Дата звернення 25.03.2020].

Крутій, К. (2009). Освітній простір дошкільного навчального закладу: [монографія]: у 2х ч. Київ : Освіта. Ч. 1.302 с.

Швалб, Ю, Вернік, О., Вовчик-Блакитна, О. та Рудоміно-Дусятська, О. (2015). Соціально-психологічні засади становлення екологічно орієнтованого способу життя особистості : монографія. Київ: Педагогічна думка. 216 с.

\section{REFERENCES}

Nova ukrainska shkola (2016). [New Ukrainian School]. Kontseptualni zasady reformuvannia serednoi shkoly. Kyiv: MON. 40 s. (in Ukrainian)

Stepanov,V. Dvorkina E. (1977). Novye tipy srednikh obrazovatelnykh shkol s gibkoi planirovochnoi strukturoi [New Types of Secondary Schools with a Flexible Planning Structure ]. Moskva: Stroiizdat. 235 s. (in Russian)

Kopylenko, N. (2001). Pedahohichnyi slovnyk [Pedagogical Dictionary]. Kyiv: Pedahohichna dumka, 2001. 516 s. (in Ukrainian)

Momot, L. ta Shelestova, L. (1997). Do problemy formuvannia tvorchykh zdibnostei u protsesi navchannia [Formation Creative Abilities in the Educational Process]. Pedahohika i psykholohiia. No 2. s. 53-59. (in Ukrainian)

Yasvin, V. (2001). Obrazovatelnaya sreda: ot modelyrovanyia k proektirovaniyu [Educational Environment: from Modeling to Design]. Moskva: Smysl, $365 \mathrm{~s}$.

Osmolovskyi, A., Vasylenko, L. (2000). Vid navchalnoho proektu do sotsialnoi samorealizatsii osobystosti [From Educational Project to Social Self-realization of a Personality]. Shliakh osvity. No 2. s.34-37. (in Russian)

Ministerstvo osvity i nauky Ukrainy (2018). Zakon Ukrainy «Pro zatverdzhennia Metodychnykh rekomendatsii shchodo orhanizatsii osvitnoho prostoru Novoi ukrainskoi shkoly [Law of Ukraine "On Approval of Methodological Recommendations for the Organization of the Educational Space of the New Ukrainian School]. URL: https://imzo.gov.ua/2018/03/25/nakazmon-vid-23-03-2018-283-pro-zatverdzhennya-metodychnyh-rekomendatsij-schodo-orhanizatsijiosvitnoho-prostoru-novoji-ukrajinskoji-shkoly/ [data zvernennia 26.03.2020] (in Ukrainian)

Vygotskii, L. (1996). Pedagogicheskaya psikhologiya [Pedagogical Psychology]. Moskva: Pedagogika-Press, 536 s.(in Russian)

Shendrik I. (2003). Obrazovatelnoe prostranstvo subekta $i$ ego proektirovanie [The Educational Space of a Person and her Creation]. Moskva: APKiPRO. 156 s. (in Russian)

Yaroshynska O. (2014). Proektuvannia osvitnoho seredovyshcha profesiinoi pidhotovky maibutnikh uchyteliv pochatkovoi shkoly : monohrafiia [Designing the Vocational Training Environment for Future Elementary School Teachers: Monograph ]. Uman: Zhovtyi O. O. 456 c. (in Ukrainian)

Vilenskii, M., Meshcheryakova, E. (2002). Obrazovatelnoe prostranstvo kak pedagogicheskaya kategoriya. [Educational Space as a Pedagogical Category] Pedagogicheskoe obrazovanie i nauka. Moskva. s. 8-18. (in Russian)

Kosenko, D. (2018). Novyi osvitnii prostir dlia Novoi ukrainskoi shkoly: misiia nezdiisnena?! [New Educational Space for the New Ukrainian School: Is Mission Unfulfilled?!] URL: http://education-ua.org/ua/articles/1115-novij-osvitnij-prostir-dlya-novoji-ukrajinskoji-shkolimisiya-nezdijsnena [Data zvernennia 20.03.2020]. (in Ukrainian) 
Kastornova, V. (2014). Nekotorye podkhody k opredeleniyu obrazovatelnogo prostranstva. [Some Approaches to the Definition of Educational Space]. Pedagogicheskoe obrazovanie $v$ Rossii. No 8. S. 43-48. (in Russian)

Tsymbalaru, A. (2016). Osvitnii prostir: sutnist, struktura i mekhanizmy stvorennia. [Educational Space: essence, structure and mechanisms of creation]. Ukrainskyi pedahohichnyi zhurnal. No $1 . \quad$ URL: http://uej.undip.org.ua/upload/iblock/311/311c4a2491b1cdb734b792dca919716e.pdf [Data zvernennia 25.03.2020]. (in Ukrainian)

Krutii, K. (2009). Osvitnii prostir doshkilnoho navchalnoho zakladu: [monohrafiia] : u 2-kh ch. [Educational Space of a Preschool Educational institution: [monograph]. Kyiv: Osvita. Ch. 1. 302 s. (in Ukrainian)

Shvalb, Yu, Vernik, O., Vovchyk-Blakytna, O. ta Rudomino-Dusiatska, O. (2015). Sotsialnopsykholohichni zasady stanovlennia ekolohichno oriientovanoho sposobu zhyttia osobystosti : monohrafiia [Socio-psychological Principles of Shaping an Environmentally Oriented Way of a Person Life: monograph]. Kyiv: Pedahohichna dumka. 216 s. (in Ukrainian)

\title{
MODERN APPROACHES TO DETERMINING THE ESSENCE OF THE CONCEPT "EDUCATIONAL SPACE"
}

\author{
Roman Pavelkiv \\ Doctor of Sciences (in Psychology),Professor, \\ First Vice-Rector, \\ Head at the Department of Age and Pedagogical Psychology, \\ Rivne State University for the Humanities, \\ Rivne, Ukraine \\ ORCID: 0000-0002-6564-4507 \\ e-mail:pavelkiv_rv@ukr.net
}

\begin{abstract}
The article describes modern approaches to determinning the essence of the concept "educational space" in the context of the implementation of the Concept "New Ukrainian School". It has been found that psychologists and educators try to strike a balance between various approaches to the study, interpretation of content and the structure of the concept of "educational space". Views of L. Vygotskyi, M. Vilenskyi, V. Kastornova, D. Kosenko, K. Krutiy, E. Meshcheryakova, I. Frumin, A. Zimbar, I. Shendryk, O. Yaroshynsky, V. Yasvin, and others on the content of the concept of "educational space" has been analyzed.

The educational space is defined as a special space where the processes of personality education take place during the transfer of culture to the younger generation, and it is considered the basic concept of the theory of pedagogy.

The basic approaches of Ukrainian and foreign scientiests to the understanding of "educational space" were characterized, for example: system-holistic, mental-emotional, personalitydevelopmental, socio-geographical, remote and locally-stand.

It was found that the use of common characteristics is common for all defined approaches: systemicity, the presence of spatial coordinates, consideration of system elements not in isolation, but holistically; informational content of the space, the territorial integrity of education, and the personal orientation of learning. The main difference between the identified approaches is the definition of the essence, the main nucleus of the educational space.
\end{abstract}


It is proved that the introduction of an appropriate proper understanding of the concept of "educational space", its distinction with the concept of "educational environment" introduces a logical understanding of the relationship of these concepts, allows to develop new concepts and ideas that have appeared in recent years, because organization the educational space of the classroom is possible to influence the motivation of the students, to create a favorable atmosphere, to satisfy the educational needs of the students of the New Ukrainian School.

So, by organizing the educational space of the classroom, one can influence the motivation of students, create a favorable atmosphere, and satisfy the educational needs of students of the New Ukrainian School.

Keywords: educational space, concepts, pedagogical approaches, New Ukrainian school, educational environment.

Стаття надійшла до редакиії 23. 04. 2020 р. 